Western North American Naturalist 70(2), (C) 2010, pp. 241-244

\title{
DISTURBANCE OF LEKKING LESSER PRAIRIE-CHICKENS (TYMPANUCHUS PALLIDICINCTUS) BY RING-NECKED PHEASANTS (PHASIANUS COLCHICUS)
}

\author{
R. Douglas Holt ${ }^{1,2}$, Matthew J. Butler ${ }^{1}$, Warren B. Ballard ${ }^{1}$, Curtis A. Kukal ${ }^{1}$ and Heather Whitlaw ${ }^{3,4}$
}

\begin{abstract}
Lesser Prairie-Chicken (Tympanuchus pallidicinctus) populations have experienced dramatic rangewide declines (up to 92\%) since settlement of the Great Plains. This decline has been attributed to changes in land-use practices, such as conversion of native rangelands to intensive agriculture and increased grazing pressure. These changes may increase the impact of interspecific competition on populations. We documented disturbance of lekking Lesser Prairie-Chickens by Ring-necked Pheasants (Phasianus colchicus). Future management and research should take into account possible impacts to Lesser Prairie-Chickens during the breeding season.
\end{abstract}

Key words: Lesser Prairie-Chicken, Tympanuchus pallidicinctus, Ring-necked Pheasant, Phasianus colchicus, lek, interspecific competition, disturbance.

Lesser Prairie-Chickens (Tympanuchus pallidicinctus) are endemic to mixed-grass and short-grass prairies of North America (Patten et al. 2005), which are dominated by shinnery oak (Quercus havardii) and sand sagebrush (Artemisia filifolia; Giesen 1998). Historic Lesser Prairie-Chicken range included portions of southwestern Kansas, southeastern Colorado, western Oklahoma, eastern New Mexico, and the Texas Panhandle (Sullivan et al. 2000).

In Texas, Lesser Prairie-Chickens currently occur in 2 distinct populations in the Panhandle (Jackson and DeArment 1963, Taylor and Guthrey 1980). These populations represent a $92 \%$ decrease from population levels of the 1800s (Taylor and Guthrey 1980, Sullivan et al. 2000). The decline in Lesser Prairie-Chicken populations is thought to be due to changes in land-use practices (Aldrich 1963, Jackson and DeArment 1963, Sullivan et al. 2000, Woodward et al. 2001) and exacerbated by droughts (Jackson and DeArment 1963, Hagen et al. 2004).

One major change of land use that may have contributed to the decline of Lesser PrairieChickens is the conversion of native rangeland to agriculture (Sullivan et al. 2000, Pitman et al. 2005). Ring-necked Pheasants (Phasianus colchicus) are well suited for landscapes consisting of grain crops interspersed with small patches of grassy cover and sparse brush and tree cover (Guidice and Ratti 2001).

Lesser Prairie-Chickens exhibit a clumped polygyny mating system (Bergerud 1988) where males gather at communal display grounds known as leks. In contrast, Ring-necked Pheasants exhibit female-defense polygyny (Oring 1982). Males establish and defend their territories and exhibit aggressive behavior toward other males (Taber 1949, Guidice and Ratti 2001).

Aggressive behavior of Ring-necked Pheasants toward Greater Prairie-Chickens (Tympanuchus cupido) on leks has been documented (Harger 1956, Vance and Westemeier 1979), though such aggression toward Lesser PrairieChickens has not been documented. Hagen et al. (2007) cautioned that interspecific competition between these species may increase as large blocks of native rangeland decrease. However, their work was based on the hypothesis that parasitism of Lesser Prairie-Chicken nests by Ring-necked Pheasants would negatively affect Lesser Prairie-Chicken populations, and they did not take into account disturbance on leks.

We observed Lesser Prairie-Chicken leks on private lands in Hemphill County, Texas, during autumn 2008 and spring 2009. The study area encompassed approximately 15,500 ha of contiguous land and was located in the rolling plains

${ }^{1}$ Department of Natural Resources Management, Texas Tech University, Box 42125, Lubbock, TX 79409-2125.

2E-mail: doug.holt@ttu.edu

${ }^{3}$ Texas Parks and Wildlife Department, Lubbock, TX 79409-2125.

${ }^{4}$ Present address: U.S. Fish and Wildlife Service, Lubbock, TX 79409-2125. 
TABLE 1. Lesser Prairie-Chicken (LEPC) lek observations during autumn 2008 and spring 2009 in Hemphill County, Texas, including mean number of Lesser Prairie-Chicken males and number of times Ring-necked Pheasants (RNPH) were observed during intervals.

\begin{tabular}{|c|c|c|c|c|c|c|c|}
\hline \multirow[b]{2}{*}{ Lek ID } & \multirow{2}{*}{$\begin{array}{l}\text { Distance to } \\
\text { nearest } \\
\text { agricultural } \\
\text { field }(\mathrm{km})\end{array}$} & \multicolumn{3}{|c|}{ Autumn 2008} & \multicolumn{3}{|c|}{ Spring 2009} \\
\hline & & $\begin{array}{l}\text { Mornings } \\
\text { observed }\end{array}$ & $\begin{array}{l}\text { Mean male } \\
\text { LEPC (SE) }\end{array}$ & $\begin{array}{c}\text { RNPH } \\
\text { observations }\end{array}$ & $\begin{array}{l}\text { Mornings } \\
\text { observed }\end{array}$ & $\begin{array}{l}\text { Mean male } \\
\text { LEPC (SE) }\end{array}$ & $\begin{array}{c}\text { RNPH } \\
\text { observations }\end{array}$ \\
\hline HEMP-01 & 0.7 & 11 & $4(0.63)$ & 0 & 18 & $4(0.24)$ & 0 \\
\hline HEMP-02 & 3.6 & 10 & $10(0.48)$ & 0 & 23 & $6(0.48)$ & 0 \\
\hline HEMP-03 & 1.3 & 17 & $6(0.98)$ & 3 & 13 & $6(0.55)$ & 4 \\
\hline HEMP-04 & 4.1 & 10 & $7(0.60)$ & 0 & 23 & $13(0.38)$ & 0 \\
\hline HEMP-05 & 1.1 & N/A & N/A & N/A & 5 & $4(0.75)$ & 0 \\
\hline HEMP-06 & 1.8 & N/A & N/A & N/A & 5 & $3(0.00)$ & 1 \\
\hline
\end{tabular}

ecoregion (Bender et al. 2005). Primary land uses were cattle ranching interspersed with oil and gas development and some Conservation Reserve Program lands, center-pivot agriculture, and dryland agriculture (McRoberts 2009).

We located leks during early morning surveys on our study area and through interviews with landowners. Early morning lek surveys were conducted systematically across the study site so that survey locations were $\leq 1.6 \mathrm{~km}$ apart. In addition, as part of a pilot study to determine the effectiveness of aerial surveys during the autumn lekking period, we conducted aerial surveys for leks during autumn 2008 (McRoberts 2009). Aerial surveys to locate leks on the study area were also conducted during spring 2009 (McRoberts 2009).

We documented observations of aggressive behavior by Ring-necked Pheasants on Lesser Prairie-Chicken leks. We observed Lesser Prairie-Chicken leks from a vehicle or blind. Observers arrived at leks at least 1 hour before sunrise, before Lesser Prairie-Chickens arrived on the lek. Observations were made through binoculars and spotting scopes. Autumn observations were conducted between 8 October and 11 November 2008. Spring observations were conducted between 4 March and 6 May 2009.

We located 4 leks on our study area during autumn 2008 and 6 leks during spring 2009 (Table 1). We observed Ring-necked Pheasants on Lesser Prairie-Chicken leks 3 times during autumn 2008 on 1 lek and 4 times during spring 2009 on 2 leks (Table 1). All Ring-necked Pheasant observations were of males.

During all observations, male Lesser PrairieChickens did not display while Ring-necked Pheasants were present on the lek. During autumn observations, we observed more complete flushes of male Lesser Prairie-Chickens and shorter durations between the beginning of lek disturbance by Ring-necked Pheasants and flushing than we observed during spring observations (Table 2). During the autumn observations, male Lesser Prairie-Chickens did not return to leks within 30 minutes. During spring observations, male Lesser Prairie-Chickens returned to the lek within 30 minutes, except for the observation on lek HEMP-06 on 1 May 2009 when male Lesser Prairie-Chickens did not return to the lek within 60 minutes.

We observed aggressive behavior of Ringnecked Pheasants toward Lesser Prairie-Chickens on leks during autumn 2008 and spring 2009. This interspecific behavior has not been previously reported in the literature. Disturbance of leks during the breeding season could prevent breeding activities and have a negative impact on populations. Baydack and Hein (1987) reported that male Sharp-tailed Grouse (Tympanuchus phasianellus) showed greater tolerance for lek disturbance than females. In fact, female Sharp-tailed Grouse altogether avoided leks when disturbance was present during peak breeding (Baydack and Hein 1987).

We define peak breeding season as the time during spring when female Lesser PrairieChickens attend leks. Female Lesser PrairieChickens were observed attending leks between 10 March and 5 April 2009. During autumn, male Lesser Prairie-Chickens generally responded to disturbance by Ring necked-Pheasants with complete flushes, and birds did not return to the lek. In contrast, during the peak breeding season, partial flushes were common, and Lesser Prairie-Chickens returned to the lek within 30 minutes of flushing. We did not observe any interaction between Ring-necked 
TABLE 2. Occurrence, duration, and result of disturbance of lekking male Lesser Prairie-Chickens by Ring-necked Pheasants during autumn 2008 and spring 2009 in Hemphill County, Texas.

\begin{tabular}{|c|c|c|c|c|c|c|}
\hline Season & Lek ID & Date & $\begin{array}{l}\text { Duration of } \\
\text { disturbance }\end{array}$ & $\begin{array}{c}\text { Result of } \\
\text { disturbance }\end{array}$ & $\begin{array}{c}\text { LEPC present } \\
\text { during disturbance }\end{array}$ & Percent flushed \\
\hline \multirow[t]{3}{*}{ Autumn 2008} & HEMP-03 & 8 Oct & $5 \mathrm{~min}$ & Complete flush & 7 & $100 \%$ \\
\hline & HEMP-03 & 18 Oct & $3 \mathrm{~min}$ & Partial flush & 7 & $14 \%$ \\
\hline & HEMP-03 & 19 Oct & $5 \min$ & Complete flush & 7 & $100 \%$ \\
\hline \multirow[t]{4}{*}{ Spring 2009} & HEMP-03 & $5 \mathrm{Mar}$ & $14 \mathrm{~min}$ & Partial flush ${ }^{\mathrm{a}}$ & 6 & $16 \%$ \\
\hline & HEMP-03 & 17 Mar & $4 \mathrm{~min}$ & No flushb & 8 & $0 \%$ \\
\hline & HEMP-03 & $3 \mathrm{Apr}$ & unknown ${ }^{\mathrm{c}}$ & unknown ${ }^{\mathrm{c}}$ & 8 & $0 \%$ \\
\hline & HEMP-06 & 1 May & unknown $^{\mathrm{d}}$ & Complete flushe & 3 & $100 \%$ \\
\hline
\end{tabular}

All remaining LEPC and RNPH flushed when Northern Harrier (Circus cyaneus) approached lek.

CLEPC and RNPH observed on lek during aerial survey; no ground observers present to document disturbance.

dRNPH present on lek when observer arrived.

eNo aggressive behavior observed prior to flushing of LEPC and RNPH.

Pheasants and female Lesser Prairie-Chickens even though we observed Ring-necked Pheasants on leks during the interval when female Lesser Prairie-Chickens were known to be in attendance at other leks. It is difficult to determine whether this observation is an artifact of the timing of female Lesser Prairie-Chicken attendance at leks or if leks were avoided by females due to the presence of Ring-necked Pheasants (Baydack and Hein 1987).

Two hypotheses have been suggested for aggressive behavior of Ring-necked Pheasants toward Greater Prairie-Chickens. The first is that female Greater Prairie-Chickens are similar in size, shape, and color to female Ring-necked Pheasants and male Ring-necked Pheasants may attempt to mate with female Greater PrairieChickens (Harger 1956). Another explanation is that since Ring-necked Pheasants are known to engage in nest parasitism (Kenaga et al. 1955, Westemeier et al. 1989, 1998), Ring-necked Pheasant chicks may imprint on other species (Kimmel 1988). Thus, because of imprinting at hatch, Ring-necked Pheasants on Greater and Lesser Prairie-Chicken leks are attempting to behave as these species (Kimmel 1988).

Lesser Prairie-Chicken populations may be declining due to a suite of disturbance factors across the landscape including habitat fragmentation and increased suitable habitat for competing species (Aldrich 1963, Jackson and DeArment 1963, Sullivan et al. 2000, Woodward et al. 2001, Hagen et al. 2004). A decline in Greater Prairie-Chicken population on a sanctuary in Illinois corresponded to an increase in Ring-necked Pheasant numbers (Westemeier 1988). In addition, Westemeier (1986) reported that Ring-necked Pheasants were the greatest threat to Greater Prairie-Chicken population persistence in Illinois. To date, previous research on the impact of interspecific competition between Lesser Prairie-Chickens and Ring-necked Pheasants has focused on nest parasitism (Hagen et al. 2002, 2007).

The role of male lek attendance and the occurrence of autumn lekking behavior in Lesser Prairie-Chickens are poorly understood. Autumn lekking behavior has been documented for the species insofar as it pertains to trapping opportunities (Salter and Robel 2000, Wolfe et al. 2007). We hypothesize that lek attendance in the autumn could be an innate response to photoperiod or that it may be a significant influence on the social structure of spring leks. If the latter is true, then the autumn lek becomes much more important under the clumped polygyny mating system (Bergerud 1988) of Lesser Prairie-Chickens. Rintamaki et al. (1999) reported that autumn lekking behavior influenced the social composition of spring leks and successful copulation attempts during the breeding season in Black Grouse (Tetrao tetrix). It is unclear what impact persistent disturbance on leks during both autumn and spring will have on population-level reproductive rates (Baydack and Hein 1987).

Future research should focus on the role of leks in population persistence and include the role of autumn lekking behavior, which is poorly understood in Lesser Prairie-Chickens. Future research should also investigate the effect on Lesser Priaire-Chickens of land-use changes and of increased disturbance associated with fragmentation. In particular, future research should attempt to determine the threshold at which fragmentation places so much stress on the population that increased interspecific competition has a negative impact at the population level. 
We thank the Texas Parks and Wildlife Department for funding our research. In addition, we express our gratitude to the private land owners in Hemphill County, Texas, who graciously allowed access to their property. This paper is Texas Tech University, College of Agricultural Science and Natural Resources Technical Publication T-9-1175.

\section{Literature Cited}

ALDRICH, J.W. 1963. Geographic orientation of American Tetraonidae. Journal of Wildlife Management 27:528545.

BAYDACK, R.K., AND D.A. HEIN. 1987. Tolerance of Sharptailed Grouse to lek disturbance. Wildlife Society Bulletin 15:535-539.

Bender, S., S. Shelton, K.C. Bender, and A. KalmBACH, EDITORS. 2005. Texas comprehensive wildlife conservation strategy: 2005-2010. Texas Parks and Wildlife Department, Austin, TX

Bergerud, A.T. 1988. Mating systems in grouse. Pages 439-472 in A.T. Bergerud and M.W. Gratson, editors, Adaptive strategies and population ecology of northern grouse. Volume 2, Theory and synthesis. University of Minnesota Press, Minneapolis, $\mathrm{MN}$.

Giesen, K.M. 1998. Lesser Prairie-Chicken (Tympanuchus pallidicinctus). No. 364 in A. Poole and F. Gill, editors, The birds of North America. The Birds of North America, Inc., Philadelphia, PA.

Guidice, J.H., AND J.T. RatTi. 2001. Ring-necked Pheasant (Phasianus colchicus). No. 572 in A. Poole and F. Gill, editors, The birds of North America. The Birds of North America, Inc., Philadelphia, PA.

Hagen, C.A., B.E. Jamison, K.M. Griesen, and T.Z. Riley. 2004. Guidelines for managing Lesser Prairie-Chicken populations and their habitats. Wildlife Society Bulletin 32:69-82.

Hagen C.A., B.E. Jamison, R.J. Robel, and R.D. AppleGATE. 2002. Ring-necked Pheasant parasitism of Lesser Prairie-Chicken nests in Kansas. Wilson Bulletin 114:522-524.

Hagen, C.A., J.C. Pitman, R.J. Robel, T.M. Loughlin, AND R.D. APPLEGATE. 2007. Niche partitioning by Lesser Prairie-Chicken Tympanuchus pallidicinctus and Ring-necked Pheasant Phasianus colchicus in southwestern Kansas. Wildlife Biology 13 (Supplement 1):1-8.

Harger, E.M. 1956. Behavior of a Ring-necked Pheasant on a prairie chicken booming ground. Wilson Bulletin 68:70-71.

JACKSON, A.S., AND R. DEARMENT. 1963. The Lesser Prairie-Chicken in the Texas panhandle. Journal of Wildlife Management 27:733-737.

Kenaga, E.E., M.A. Wolf, And A.E. Doty. 1955. A mixed clutch of Ruffed Grouse and Ring-necked Pheasant eggs hatch on the same day. Auk 72:80-81.

Kimmel, R.O. 1988. Potential impacts of Ring-necked Pheasants on other game birds. Pages 253-265 in D.L. Hallett, W.R. Edwards, and G.V. Burger, editors, Pheasants: symptoms of wildlife problems on agricultural lands. North Central Section of The Wildlife Society, Milwaukee, WI.
McRoberts, J.T. 2009. Aerial surveys for Lesser PrairieChicken leks: detectability and disturbance response. Master's thesis, Texas Tech University, Lubbock, TX.

Oring, L.W. 1982. Avian mating systems. Pages 1-92 in D.S. Farner, J.R. King, and K.C. Parkes, editors, Avian Biology. Volume 6. Academic Press, New York, NY.

Patten, M.A., D.H. Wolfe, E. Shochat, and S.K. SherROD. 2005. Habitat fragmentation, rapid evolution and population persistence. Evolutionary Ecology Research 7:235-249.

Pitman, J.C., C.A. Hagen, R.J. Robel, T.M. Loughlin, AND R.D. ApPlEgate. 2005. Location and success of Lesser Prairie-Chicken nests in relation to vegetation and human disturbance. Journal of Wildlife Management 69:1259-1269.

Rintamaki, P.T., E. Karvonen, R.V. Alatalo, and A. LundBERG. 1999. Why do Black Grouse males perform on lek sites outside the breeding season? Journal of Avian Biology 30:359-366.

Salter, G.C., and R.J. Robel. 2000. Capturing Lesser Prairie-Chickens on leks during fall. Transactions of the Kansas Academy of Science 103:46-47.

Sullivan, R.M., J.P. Hughes, and J.E. LiOnberger. 2000. Review of the historical and present status of the Lesser Prairie-Chicken (Tympanuchus pallidicinctus) in Texas. Prairie Naturalist 32:177-188.

TABER, R.D. 1949. Observations on the breeding behavior of the Ring-necked Pheasant. Condor 51:153-175.

Taylor, M.A., AND F.S. Guthrey. 1980. Status, ecology, and management of the Lesser Prairie-Chicken. U.S. Department of Agriculture Forest Service Technical Report RM-77, Rocky Mountain Forest and Range Experiment Station, Fort Collins, CO.

VAnCE, D.R., AND R.L. WestemeIER. 1979. Interactions of pheasants and prairie chickens in Illinois. Wildlife Society Bulletin 7:221-225.

Westemeier, R.L. 1986. Endangered prairie-chickens and some species interactions. Illinois Natural History Survey Report 262:1-2.

1988. An evaluation of methods for controlling pheasants on Illinois prairie-chicken sanctuaries. Pages 267-288 in D.L. Hallett, W.R. Edwards, and G.V. Burger, editors, Pheasants: symptoms of wildlife problems on agricultural lands. North Central Section of The Wildlife Society, Milwaukee, WI.

Westemeier, R.L., J.E. Buhnerkempe, W.R. Edwards, J.D. Braun, AND S.A. Simpson. 1998. Parasitism of Greater Prairie-Chicken nests by Ring-necked Pheasants. Journal of Wildlife Management 62:854-863.

Westemeier, R.L., T.L. Esker, and S.A. Simpson. 1989. An unsuccessful clutch of Northern Bobwhites with hatched pheasant eggs. Wilson Bulletin 101:640-642.

Wolfe, D.H., M.A. Patten, E. Shochat, C.L. Pruett, AND S.K. Sherrod. 2007. Causes and patterns of mortality in Lesser Prairie-Chickens Tympanuchus pallidicinctus and implications for management. Wildlife Biology 13 (Supplement 1):95-104.

Woodward, A.J.W., S.D. Fuhlendorf, D.M. Leslie JR., AND J. ShackFord. 2001. Influence of landscape composition and change on Lesser Prairie-Chicken (Tympanicus pallidicinctus) populations. American Midland Naturalist 145:261-274.

Received 22 September 2009 Accepted 7 January 2010 